\title{
PENGARUH STRES DAN DISIPLIN KERJA KARYAWAN TERHADAP KEPUASAN DAN KINERJA KARYAWAN PT. BANK PERKREDITAN RAKYAT (BPR) MITRATHAMA ARTHABUANA DI KABUPATEN BANJAR
}

\author{
Elida Mahriani
}

Dosen Fakultas Ekonomi dan Bisnis Islam UIN Antasari Banjarmasin

\begin{abstract}
Employee Performance can be measured from their compliance with company policy, the ability to complete the jobs, the timing of completing the work, the quality of results. On the other hand, a too tight work can affect the psychological state of the employees, which may also then affect their performance. The study are conducted in BPR Mitrathama Arthabuan of Kabupaten Banjar, to answer the formulation below: (1) Do stress and work discipline partially affect on job satisfaction of employees?; (2) Do stress and work discipline partially affect on Employee Performance?, and (3) Does Satisfaction affect the performance of employees? This study uses Quantitative Methods, the data is taken via questionnaires, and then analyzed using Partial Least Square (PLS) model with t-test via smartPLS software version 2.0.M3. The result of the research: (1) The t-statistic value of the path of influence of Stress on Satisfaction is 9,464 and to Satisfaction and Performance is 2,617 bigger than t-table of normal distribution (1,96), meaning significant, hypothesis 1 accepted. (2) The t-statistic value of Discipline effect on Satisfaction is 3,190 and to Satisfaction and Performance is 2,617 bigger than tnormal distribution table (1,96), meaning significant, hypothesis 2 accepted. (3) The t-statistic value of the influence of Satisfaction on Performance is 2,617 is greater than the normal t-distribution table (1,96), meaning significant, hypothesis 3 is accepted.
\end{abstract}

Kata Kunci: Stress; Discipline; Satisfaction; Performance

\section{Pendahaluan}

Secara sederhana bisnis berarti suatu sistem guna memproduksi barang dan jasa untuk memuaskan kebutuhan masyarakat. Karena ia merupakan suatu sistem dalam masyarakat, maka ada hubungan timbal balik antara bisnis dan unsurunsur lain dimasyarakat. Setiap tindakan yang dilakukan bisnis mempengaruhi sistem sosial yang lebih besar. Sistem bisnis tidak terlepas dari sistem politik, dan merupakan bahagian daripada sistem ekonomi, serta bergerak didalam suatu sistem hukum. ${ }^{1}$

Pada dasarnya, sebuah sistem perusahaan memperoleh masukan dari lingkungannya, lalu memproduksinya, dan kemudian menghasilkan sesuatu untuk kepentingan sistem yang lebih besar. ${ }^{2}$ Departemen sumber daya manusia di perusahaan- perusahaan saat ini tidak hanya menyokong tujuan-tujuan strategis tetapi juga secara aktif berusaha mengejar rencana rutin dan terpadu dalam memajukan kinerja organisasi. ${ }^{3}$ Pendekatan strategis terhadap manajemen sumber daya manusia terdiri atas tiga unsur penting. Pertama, semua manajer dilibatkan dalam manajemen sumber daya manusia. Kedua, para pegawai dipandang sebagai aset. Para pegawai

\footnotetext{
1 M. Manulang, Pengantar Bisnis, Gadjah Mada University Press: Yogyakarta, 2002, hlm.9.0

${ }^{2}$ Ibid, hlm. 10.

3 Ricard L. Draft, Era Baru Manajemen Edisi 9 Buku 2

(Terjemah), Salemba Empat: Jakarta, 2012, hlm. 96.
}

bukan bangunan maupun mesin, dapat memberikan daya saing pada perusahaan. Ketiga, manajemen sumber daya manusia adalah proses penyesuaian, yang memadukan strategi dan tujuan organisasi dengan pendekatan yang tepat dalam mengelola modal manusia. Dalam perusahaanperusahaan yang melakukan pendekatan strategis, manajer-manajer sumber daya manusia adalah pemain kunci dalam tim eksekutif dan memerankan peran sangat penting dalam menggerakan kinerja. ${ }^{4}$

Sebuah organisasi dijalankan dengan beragam pekerjaan yang ada. Sebuah prinsip dasar menyatakan bahwa sebuah pekerjaan dapat dilakukan dengan lebih efisien jika orang-orang yang melakukannya adalah mereka yang fokuskan untuk pekerjaan tersebut. Spesialisasi kerja (work specialization), yang terkadang juga disebut divisi kerja, adalah kadar yang digunakan untuk membagi-bagi tugas-tugas organisasi menjadi pekerjaan-pekerjaan yang lebih spesifik. ${ }^{5}$

Pengembangan suatu struktur organisasi merupakan akibat dari adanya pekerjaan-pekerjaan yang harus diisi dengan orang-orang yang akan melaksanakannya. Analisis pekerjaan adalah prosedur untuk menentukan tugas-tugas dan hakekat pekerjaan serta jenis orang (berkaitan dengan keterampilan dan pengalaman) yang perlu

\footnotetext{
${ }^{4}$ Ibid, hlm. 97.

${ }^{5}$ Ricard L. Draft, Op.Cit, hlm. 5.
} 
diangkat untuk melaksanakannya. Analisis pekerjaan menyediakan data tentang syarat pekerjaan, yang kemudian digunakan untuk menyusun uraian pekerjaan (job description) hal-hal yang tercakup dalam pekerjaan dan spesifikasi pekerjaan (job specification) jenis orang yang diangkat untuk melaksanakan pekerjaannnya. ${ }^{6}$

PT.Bank Perkreditan Rakyat (BPR) Mitrathama Arthabuana merupakan lembaga perbankan yang mempunyai fungsi untuk menghimpun dan menyalurkan dana ke masyarakat, serta memberikan jasa-jasa lain ke masyarakat luas seperti memberikan layanan pembayaran Listrik, pembayaran PDAM, pembelian voucer pulsa. Untuk meningkatkan layanan ke masyarakat PT. Bank Perkreditan Rakyat (BPR) di Kabupaten Banjar memerlukan karyawan-karyawan yang handal dalam melakukan pekerjaannya agar dapat bersaing dengan perbankan yang lain. Kinerja Karyawan dapat diketahui setelah adanya penerapan disiplin kerja dari PT.Bank Perkreditan Rakyat (BPR) Mitrathama Arthabuana, diantaranya dapat diukur dari ketaatan terhadap kebijakan-kebijakan tentang peraturan-peraturan perusahaan, kemampuan dalam menyelesaikan pekerjaan-pekerjaan, ketetapan waktu dalam menyelesaikan pekerjaan, kualitas hasil dalam pelaksanaan pekerjaan. Ini dapat terlihat apakah ada karyawan tersebut mengalami stres dalam menyelesaikan tugas nya sesuai dengan pekerjaan yang diemban nya. Karena pekerjaan yang terlalu ketat dapat mempengaruhi keadaan psikologis dari para karyawan tersebut, hal ini juga bisa berdampak pada kedisiplin dan kepuasan kerja serta kinerja dari karyawan.

Maka dari itu, Pengelolaan stres kerja sangat diperlukan untuk mendukung kepuasan kerja karyawan di PT. Bank Perkreditan Rakyat (BPR) di Kabupaten Banjar, fenomena ini bisa dilihat menurunnya produktivitas kerja karyawan apabila stres mereka tidak ditangani dengan serius oleh sebab itu para pimpinan perusahaan seharusnya menjebatani permasalahan ini, agar dapat mengelola stres tersebut dengan baik dengan memberikan konsling atau pembimbingan.

Berdasarkan latar belakang diatas, maka dapat disimpulkan bahwa artikel ini bertujuan untuk menjawab pertanyaan-pertanyaan berikut:

6 Gary Dessler, Manajemen Personalia Edisi Ketiga (Terjemahan), Erlangga: Jakarta, 1984, hlm. 85.
1. Bagaimana diskripsi Stres, Disiplin, Kepuasan dan Kinerja Karyawan PT. Bank Perkreditan Rakyat (BPR) Mitrathama Arthabuana di Kabupaten Banjar?

2. Apakah Stres, Disiplin Kerja berpengaruh secara parsial terhadap kepuasan kerja karyawan PT.Bank Perkreditan Rakyat (BPR) Mitrathama Arthabuana di Kabupaten Banjar?

3. Apakah Stres, Disiplin Kerja berpengaruh secara parsial terhadap Kinerja karyawan PT.Bank Perkreditan Rakyat (BPR) Mitrathama Arthabuana di Kabupaten Banjar?

4. Apakah Kepuasan berpengaruh terhadap Kinerja karyawan PT.Bank Perkreditan Rakyat (BPR) Mitrathama Arthabuana di Kabupaten Banjar?

\section{Studi Literatur}

Bank adalah sebuah lembaga atau perusahaan yang aktivitasnya menghimpun dana berupa giro, deposito tabungan dan simpanan yang lain dari pihak yang kelebihan dana (surplus spending unit) kemudian menempatkannya kembali kepada masyarakat yang membutuhkan dana (deficit spending unit) melalui penjualan jasa keuangan pada gilirannya dapat meningkatkan kesejahteraan rakyat banyak. Pada pengertian diatas tampak sangat statistik, bank sebagai lembaga atau badan usaha. Sedangkan pengertian perbankan sangat dinamis. Perbankan adalah segala sesuatu yang berkiatan dengan bank, mencakup kelembagaan, kegiatan usaha, serta cara dan proses dalam melaksanakan kegiatan usahanya. Kegiatan usaha tersebut adalah menyangkut jasa keuangan. Dalam Perspektif ilmu keuangan, perbankan adalah bagian dari ilmu keuangan. ${ }^{7}$

Dunia perbankan Indonesia yang telah mengalami perubahan orientasi. Sebelum tahun 1980-an, bank-bank masih merupakan lembaga yang berorientasi pada produk. Masyarakat yang membutuh pelayanan bank harus datang dan mencari bank. Pelayanan bank belum sebaik sekarang karena bank komersial masih menganut konsep menjual produk atau jasa. Pertimbangan kepuasan pelanggan/nasabah belum menjadi orientasi bank. Berbeda dengan kondisi setelah Paket Kebijakan Juni (Pakjun) 1983, bank telah

7 Taswan, Manajemen Perbankan: Konsep, Teknik dan Aplikasi Edisi II, UPP STIM YKPN: Yogyakarta, 2010, hlm. 6 
tumbuh spektakuler baik menyangkut jumlah bank, cabang bank maupun jumlah produk/jasa yang ditawarkan. Dengan demikian orientasi pelayanan yang unggul dan pengembangan produk dan jasa perbankan yang dibutuhkan masyarakat harus dilakukan oleh bank. Pendek kata product oriented telah bergeser ke customer oriented. 8

Bank umum adalah bank yang melaksanakan kegiatan usahanya secara konvensional dan atau berdasarkan prinsip syariah yang dalam kegiatannya memberikan jasa dalam lalu lintas pembayaran. Sifat jasa yang diberikan adalah umum, dalam arti dapat memberikan seluruh jasa perbankan yang ada. ${ }^{9}$

Bank Perkreditan Rakyat (BPR)n adalah bank yang melaksanakan kegiatan usaha secara konvensional atau berdasarkan prinsip syariah. Dalam kegiatannya BPR tidak memberikan jasa dalam lalu lintas pembayaran. Artinya jasa-jasa perbankan yang ditawarkan BPR jauh lebih sempit jika dibandingkan dengan kegiatan atau jasa bank umum. ${ }^{10}$ berikut:

Dalam praktiknya kegiatan BPR sebagai

1. Menghimpun dana hanya dalam bentuk:
a. Simpanan Tabungan
b. Simpanan Deposito

2. Menyalurkan dana dalam bentuk:
a. Kredit Investasi
b. Kredit Modal Kerja
c. Kredit Perdagangan ${ }^{11}$

Karena keterbatasan yang dimiliki oleh BPR, maka ada beberapa larangan yang tidak boleh dilakukan BPR. Larangan ini meliputi hal-hal sebagai beikut:

1. Menerima simpanan giro

2. Mengikuti kliring

3. Melakukan kegiatan valuta asing

4. Melakukan kegiatan perasuransian. ${ }^{12}$

\section{A. Stres Kerja}

Elemen penting lain dari perilaku dalam organisasi adalah stres, yaitu reaksi seorang

\footnotetext{
8 Taswan, Akuntansi Perbankan: Transaksi Dalam Valuta Rupiah, Edisi Revisi, UPP STIM YKPN: Yogyakarta, 2003, hlm.1.

${ }_{9}$ Kasmir, Dasar-Dasar Perbankan, Rajawali Pers: Jakarta, 2002, hlm. 19.

${ }^{10} \mathrm{Ibid}, \mathrm{hlm} .20$

${ }^{11}$ Ibid, hlm. 37.

12 Ibid, hlm. 38.
}

individu terhadap rangsangan yang kuat. Rangsangan ini dinamakan penyebab stres (stressor). Stres umumnya mengikuti siklus yang dinamakan sindrom adaptasi umum (general adaptation syndrome atau GAS). ${ }^{13}$

Pada dasarnya berbagai sumber stres dapat digolongan pada yang berasal dari pekerjaan dan dari luar pekerjaan seseorang. Berbagai hal yang dapat menjadi sumber stres yang berasal dari pekerjaan pun dapat beraneka ragam seperti beban tugas yang terlalu berat, desakan waktu, penyeliaan yang kurang baik, iklim kerja yang menimbulkan rasa tidak aman, kurangnya informasi dari umpan balik tentang prestasi kerja seseorang, ketidakseimbangan antara wewenang dan tanggung jawab, ketidakjelasan peranan karyawan dalam keseluruhan kegiatan organisasi, frustasi yang ditimbulkan oleh intervensi pihak lain yang terlalu sering sehingga seseorang merasa terganggu konsentrasinya, konflik antara karyawan dengan pihak lain didalam atau diluarkelompok kerjanya, perbedaan sistem nilai yang dianut oleh karyawan dan yang dianut oleh organisasi dan perubahan yang terjadi yang pada umumnya memang menimbulkan rasa ketidakpastian. ${ }^{14}$

\section{B. Disiplin Kerja}

Kedisiplinan diartikan sebagai kesadaran dan kesediaan seseorang mentaati semua pertauran perusahaan dan norma-norma sosial yang berlaku. Kesadaran disini adalah sikap yang secara sukarela mentaati semua peraturan dan sadar akan tugas dan tanggung jawabnya. Jadi, dia akan mematuhi/mengerjakan semua tugasnya dengan baik bukan atas paksaan. Sedangkan kesediaan adalah suatu sikap, tingkah laku dan perbuatan seseorang sesuai dengan pertauran perusahaan yang tertulis maupun tidak. ${ }^{15}$

Menurut Handoko ada dua tipe kegiatan pendisiplian, yaitu:

1. Disiplin Preventif adalah kegiatan yang dilaksanakan untuk mendorong para karyawan agar mengikuti berbagai standar dan aturan, sehingga penyelewenganpenyelewengan dapat dicegah. Sasaran pokoknya adalah untuk mendorong disiplin diri mereka bukan semata-semata

\footnotetext{
13 Sunarto, Manajemen 2, Amus: Yogyakarta, 2007, hlm.147.

14 Sondang P. Siagian, Manajemen Sumber Daya Manusia, Bumi Aksara: Jakarta, 1998, hlm. 31.

${ }^{15}$ Hasibuan Malayu SP, Manajemen Sumber Daya Manusia, PT Gunung Agung: Jakarta, 2007, hlm. 212.
} 
karena dipaksa manajemen, manajemen mempunyai tanggung jawab unutk menciptakan sautu disiplin preventif dimana berbagai standar diketahui dan dipahami. Bila para karyawan tidak mengetahui standar-standar apa yang harus dicapai, mereka cenderung menjadi salah arah atau eratik.

2. Disiplin Korektif, adalah kegiatanyang diambil untuk menangani pelanggaran terhadap aturan-aturan dan mencoba untuk menghindari pelanggaranpelanggaran lebih lanjut. Kegiatan korektif sering berupa suatu bentuk hukuman dan disebut tindakan pendisiplinan (diciplinaryaction) ${ }^{16}$

\section{Kepuasan Kerja}

Kepuasan kerja (Job statisfaction) adalah keadaan emosional yang menyenangkan atau tidak menyenangkan dengan para menyadang pekerjaan mereka. Kepuasan kerja tercerminkan perasaaan seseorang terhadap pekerjaannya. Ini nampak dalam sikap positif karyawan terhadap pekerjaan dan segala sesuatu yang dihadapi di lingkungan kerjanya. Departemen personalia atau manajemen harus senantiasa memonitor kepuasan kerja, karena hal itu mempengaruhi tingkat absensi, perputaran tenaga kerja, semangat kerja, keluhan-keluhan, dan masalah-masalah personalia vital lainnya. ${ }^{17}$

\section{Penilaian Kinerja}

Menurut Veithzal Rivai, kinerja merupakan suatu fungsi dari motivasi dan kemampuan untuk menyelesaikan tugas atau pekerjaan seseorang sepatutnya memiliki derajat kesediaan dan tingkat kemampuan tertentu, atau kinerja adalah perilaku nyata yang ditampilkan setiap orang sebagai prestasi kerja yang dihasilkan oleh karyawan sesuai dengan perannya dalam perusahaan. ${ }^{18}$ Penilaian kinerja juga membutuhkan penetapan standar kinerja, dan berasumsi bahwa karyawan menerima pelatihan, umpan balik, insentif yang dibutuhkan untuk menghilangkan defisiensi kinerja. Pada intinya, penilaian kinerja selalu

16 T. Hani Handoko, Manajemen Personalia dan Sumber Daya Manusia, Liberty: Yogyakarta, 2001, hlm. 208.

17 T. Hani Handoko, Manajemen Personalia dan Sumber Daya Manusia Edisi 2,BPFE: Yogyakarta, 2012, hlm, 193-194.

18 Veithzal Rivai, Bagaimana Meningkatkan Kinerja Karyawan Bank, Survei Di Bank Negara Indonesia dan Bank Mandiri, Jurnal Ekonomi Perusahaan, Vol. 10 STIE IBII: Jakarta, 2003, hlm.309. melibatkan proses penilaian kinerja (performance apprasial procces) tiga langkah: (1) menetapkan standar kerja; (2) menilai kinerja aktual karyawan secara relatif terhadap standar (ini biasanya melibatkan beberapa formulir penilaian); (3) memberikan umpan balik kepada karyawan dengan tujuan membantunya untuk menghilangkan defisiensi kinerja atau untuk berkinerja diatas standar. ${ }^{19}$

\section{Metode Penelitian}

\section{A. Kerangka Konseptual Penelitian}

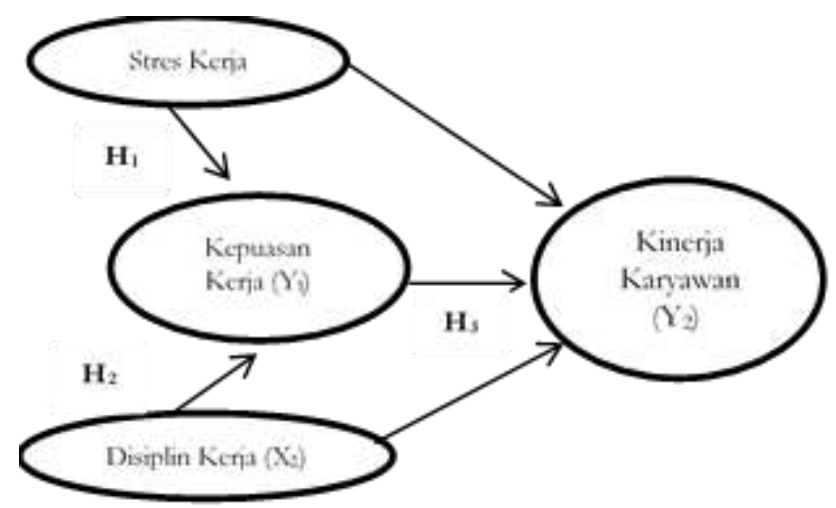

Gambar 1. Kerangka Konseptual

\section{B. Penilaian Kinerja}

Adapun hipotesis yang diajukan dalam penelitian ini adalah sebagai berikut:

$\mathrm{H}_{1}$ : Terdapat pengaruh stres dan disiplin secara parsial terhadap kepuasan Kerja Karyawan PT. Bank Perkreditan Rakyat (BPR) Mitrathama Arthabuana di Kabupaten Banjar.

$\mathrm{H}_{2}$ : Terdapat pengaruh stres dan disiplin secara parsial terhadap Kinerja Karyawan PT. Bank Perkreditan Rakyat (BPR) Mitrathama Arthabuana di Kabupaten Banjar.

$\mathrm{H}_{3}$ : Terdapat pengaruh kepuasan dan kinerja pada Karyawan PT. Bank Perkreditan Rakyat (BPR) Mitrathama Arthabuana di Kabupaten Banjar.

$\mathrm{H}_{4}$ : Terdapat pengaruh stres dan disiplin kerja pada Karyawan PT. Bank Perkreditan Rakyat (BPR) Mitrathama Arthabuana di Kabupaten Banjar.

\section{Variabel Penelitian dan Definisi Operasional}

1. Variabel Bebas

${ }^{19}$ Gary Dessler, Manajemen Sumber Daya Manusia Edisi 14 (Terjemahan), Salemba Empat: Jakarta, 2015, hlm. 330. 
Variabel bebas yang digunakan dalam penelitian ini yaitu: Stres $\left(\mathrm{X}_{1}\right)$ dan Disiplin Kerja $\left(\mathrm{X}_{2}\right)$

2. Variabel Terikat
Variabel terikat yang digunakan dalam penelitian ini yaitu: Kepusan Kerja $\left(\mathrm{Y}_{1}\right)$ dan Kinerja Karyawan $\left(\mathrm{Y}_{2}\right)$.

Tabel 1. Variabel Penelitian dan Definisi Operasional

\begin{tabular}{|c|c|c|c|c|}
\hline No & Variabel & Definisi Operasional & Indikator & Skala \\
\hline 1. & $\begin{array}{l}\text { Stres Kerja } \\
\text { (Menurut Hani } \\
\text { Handoko, 2011) }\end{array}$ & $\begin{array}{l}\text { Kondisi ketegangan yang } \\
\text { mempengaruhi emosi, } \\
\text { proses berpikir dan kondisi } \\
\text { psikologis karyawan }\end{array}$ & $\begin{array}{l}\text { 1. Beban kerja yanng berlebihan } \\
\text { 2. Tekanan atau desakan waktu } \\
\text { 3. Kualititas suvervisi yang jelek } \\
\text { 4. Iklim politis yang tidak aman } \\
\text { 5. Umpan balik tentang pelaksanaan } \\
\text { kerja yang tidak memadai } \\
\text { 6. Wewenang yang tidak mencukupi } \\
\text { untuk melaksanakan tanggung } \\
\text { jawab } \\
\text { 7. Kemenduan peran (role ambiguity) } \\
\text { 8. Frustasi } \\
\text { 9. Konflik antar pribadi } \\
\text { 10. Perbedaan antara nilai-nilai } \\
\text { perusahaan dan karyawan } \\
\text { 11. Berbagai bentuk perubahan }\end{array}$ & Likert \\
\hline 2 & $\begin{array}{l}\text { Disiplin Kerja } \\
\text { (Menurut } \\
\text { Hasibuan, 2007) }\end{array}$ & $\begin{array}{l}\text { Kegiatan yang disusun dan } \\
\text { diatur oleh manajemen } \\
\text { untuk menjalankan standar- } \\
\text { standar organisasional atau } \\
\text { perusahaan }\end{array}$ & $\begin{array}{l}\text { 1. Teladan pimpinan } \\
\text { 2. Balas jasa } \\
\text { 3. Waskat (Pengawasan melekat) } \\
\text { 4. Sanksi hukum } \\
\text { 5. Ketegasan pimpinan }\end{array}$ & Likert \\
\hline 3 & $\begin{array}{l}\text { Kepuasan Kerja } \\
\text { (Menurut } \\
\text { Robbins, 1996) }\end{array}$ & $\begin{array}{l}\text { Perasaan karyawan tentang } \\
\text { menyenangjan atau tidaknya } \\
\text { terhadap pekerjaan yang } \\
\text { mereka kerjakan }\end{array}$ & $\begin{array}{l}\text { 1. Kerja yang secara mental } \\
\text { menantang } \\
\text { 2. Ganjaran yang pantas } \\
\text { 3. Kondisi kerja yang mendukung } \\
\text { 4. Rekan kerja yang mendukung } \\
\text { 5. Kesesuaian kepribadian pekerjaan }\end{array}$ & Likert \\
\hline 4 & $\begin{array}{l}\text { Kinerja } \\
\text { Karyawan } \\
\text { (Menurut } \\
\text { Wibowo, 2007) }\end{array}$ & $\begin{array}{l}\text { Hasil kerja dari karyawan } \\
\text { dalam melakukan } \\
\text { pekerjaannya dalam periode } \\
\text { tertentu dan menekankan } \\
\text { pada hasil yang telah } \\
\text { dilakukan. }\end{array}$ & $\begin{array}{l}\text { 1. Tujuan } \\
\text { 2. Standar } \\
\text { 3. Umpan balik } \\
\text { 4. Alat atau sarana } \\
\text { 5. Kompetensi } \\
\text { 6. Motif } \\
\text { 7. Peluang }\end{array}$ & Likert \\
\hline
\end{tabular}

\section{Populasi dan Sampel}

Populasi dan penelitian ini adalah semua Karyawan PT. Bank Perkreditan Rakyat (BPR) Mitrathama Arthabuana di Kabupaten Banjar. Sampel untuk penelitian ini adalah 40 orang karyawan PT.Bank Perkreditan Rakyat (BPR) Mitrathama Arthabuana di Kabupaten Banjar.

\section{E. Teknik Pengambilan Sampel}

Menurut (Arikunto, 2002) jika populasi kurang dari 100 maka semua akan menjadi sampel. Namun jika populasi lebih dari 100 maka akan diambil sampel 5\%-10\% atau 20\%$30 \%$ dari jumlah populasi. Namun, pada penelitian ini total populasi sebanyak 40 orang karyawan PT.Bank Perkreditan Rakyat (BPR)
Mitrathama Arthabuana di Kabupaten Banjar. Sehingga semua populasi dijadikan sebagai sampel atau teknik pengambilan sampel dengan menggunakan teknik jenuh atau sensus.

\section{F. Prosedur Pengumpulan Data}

Data yang digunakan dalam penelitian ini diperoleh dengan cara memberikan alternatif pertanyaan-pertanyaan secara tertulis (kuesioner) kepada responden. Metode pengumpulan data kuesioner pada penelitian ini menggunakan metode personnally administrated questionnaires, yaitu dimana peneliti menyampaikan sendiri kuesioner kepada responden dan mengambil sendiri kuesioner kepada responden. Hal ini bertujuan supaya 
tingkat pengembalian kuesioner dapat terjaga dalam periode waktu yang relatif pendek (Sekaran, 2003). Skala yang digunakan dalam penelitian ini adalah skala likert. Skala ini berinterasi 1-5 dengan pilihan jawaban sebagai berikut:

1. Sangat Tidak Setuju (STS)

2. Tidak Setuju (TS)

3. Cukup Setuju (CS)

4. Setuju (S)

5. Sangat Setuju (SS)

\section{G. Analisis Data}

Analisis yang digunakan dalam penelitian ini menggunakan model Partial Least Square (PLS) dengan uji-t. PLS merupakan metode analisis yang powerful oleh karena tidak didasarkan banyak asumsi. PLS sebagai teknik analisis data dengan software smartPLS versi 2.0.M3.

\section{Hasil Penelitian dan Pembahasan}

Berdasarkan hasil penelitian, diketahui bahwa mayoritas responden yang diteliti adalah perempuan yaitu sebanyak 52,5\%. Sedangkan responden laki-laki sebanyak 47,5\%. Hal ini menunjukan bahwa minat kerja di PT. Bank Perkreditan Rakyat (BPR) Mitrathama Arthabuana didominasi oleh perempuan Karakteristik responden penelitian menurut jenis kelamin dapat dilihat pada tabel 2 berikut:

Tabel 2. Distribusi Frekuensi Responden Menurut Jenis Kelamin

\begin{tabular}{ccc}
\hline Jenis Kelamin & Jumlah & Persentase (\%) \\
\hline Perempuan & 21 & 52,5 \\
\hline Laki-Laki & 19 & 47,5 \\
\hline Jumlah & $\mathbf{4 0}$ & $\mathbf{1 0 0 , 0 0}$ \\
\hline
\end{tabular}

Berdasarkan hasil penelitian, diketahui bahwa sebagian besar responden yang diteliti adalah berdasarkan bagian nya Teller sebanyak 12,5\%. Kemudian Costumer Service (CS) sebanyak 7,5\%, Review \& Remedial sebanyak 7,5\%, Account Officer (AO) sebanyak 10\%, Administrasi Kredit sebanyak 32,5\%, Marketing sebanyak 15\%, Keuangan sebanyak 2,5\%, Audit sebanyak 2,5\%, pengembangan \& perencanaan sebanyak $2,5 \%$, Driver sebanyak 2,5\% dan Security sebanyak 5\%. Hal ini menunjukan bahwa bagian kerja yang terbanyak di PT. Bank Perkreditan Rakyat (BPR) Mitrathama Arthabuana adalah Administrasi Kredit. Karakteristik responden penelitian menurut pendidikan dapat dilihat pada Tabel 3 berikut:
Tabel 3. Distribusi Frekuensi Responden Menurut Bagian

\begin{tabular}{lcc}
\hline \multicolumn{1}{c}{ Bagian } & Jumlah & Persentase (\%) \\
\hline Teller & 5 & 12,5 \\
\hline $\begin{array}{l}\text { Customer Service } \\
(\mathrm{CS})\end{array}$ & 3 & 7,5 \\
\hline Review \& Remedial & 3 & 7,5 \\
\hline $\begin{array}{l}\text { Account Officer } \\
(\text { AO) }\end{array}$ & 4 & 10 \\
\hline Administrasi Kredit & 13 & 32,5 \\
\hline Marketing & 6 & 15 \\
\hline Keuangan & 1 & 2,5 \\
\hline Audit & 1 & 2,5 \\
\hline $\begin{array}{l}\text { Pengembangan \& } \\
\text { perencanaan }\end{array}$ & 1 & 2,5 \\
\hline Driver & 1 & 2,5 \\
\hline Security & 2 & 5 \\
\hline \multicolumn{1}{c}{ Jumlah } & $\mathbf{4 0}$ & $\mathbf{1 0 0 , 0 0}$ \\
\hline
\end{tabular}

Berdasarkan hasil penelitian, diketahui bahwa sebagian besar responden yang diteliti adalah Status Karyawan, yaitu karyawan tetap sebanyak $52,5 \%$. Kemudian karyawan kontrak antara sebanyak 47,5\%. Hal ini menunjukan bahwa Status Karyawan yang terbanyak di PT. Bank Perkreditan Rakyat (BPR) Mitrathama Arthabuana adalah Karyawan tetap. Karakteristik responden penelitian menurut pendidikan dapat dilihat pada Tabel 4 berikut:

Tabel 4. Distribusi Frekuensi Responden Menurut Status Karyawan

\begin{tabular}{lcc}
\hline Status Karyawan & Jumlah & Persentase (\%) \\
\hline Tetap & 21 & 52,5 \\
\hline Kontrak & 19 & 47,5 \\
\hline \multicolumn{1}{c}{ Jumlah } & $\mathbf{4 0}$ & $\mathbf{1 0 0 , 0 0}$ \\
\hline
\end{tabular}

Berdasarkan hasil penelitian, diketahui bahwa sebagian besar responden yang diteliti adalah Status Perkawinan Karyawan yaitu Belum Menikah sebanyak 32,5\%. Kemudian Menikah sebanyak 62,5\%, dan cerai mati sebanyak 5\%. Hal ini menunjukan bahwa Status Perkawinan Karyawan yang terbanyak di PT. Bank Perkreditan Rakyat (BPR) Mitrathama Arthabuana adalah Menikah. Karakteristik responden penelitian menurut pendidikan dapat dilihat pada Tabel 5 berikut:

Tabel 5. Distribusi Frekuensi Responden Menurut Status Perkawinan

\begin{tabular}{lcc}
\hline Status Perkawinan & Jumlah & Persentase (\%) \\
\hline Belum Menikah & 13 & 32,5 \\
\hline Menikah & 25 & 62,5 \\
\hline
\end{tabular}




\begin{tabular}{ccc}
\hline Cerai Mati & 2 & 5 \\
\hline Jumlah & $\mathbf{4 0}$ & $\mathbf{1 0 0 , 0 0}$ \\
\hline
\end{tabular}

Hasil Uji Validitas dan Reliabilitas Instrumen Penelitian

\section{A. Convergent Validity}

Dari model pengukuran dengan indikator reflektif, indikator dinilai berdasarkan korelasi item skor/komponan skor dengan konstruk skor yang dihitung dengan Aplikasi PLS. Ukuran reflektif dianggap valid jika memiliki nilai loading di atas 0,50 dan atau t-Statistic di atas 1,96 .

Tabel 6. Outer Model pada Uji Validitas Instrumen Penelitian

\begin{tabular}{|c|c|c|c|c|c|}
\hline \\
\hline & $\underset{\mathbb{R}}{\mathbb{Z}}$ & & 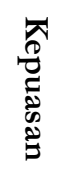 & & 苋: \\
\hline $\mathrm{X} 1.2$ & 0.583 & & & & Valid \\
\hline $\mathrm{X} 1.21$ & 0.784 & & & & Valid \\
\hline $\mathrm{X} 1.22$ & 0.528 & & & & Valid \\
\hline X1.4 & 0.581 & & & & Valid \\
\hline $\mathrm{X} 1.5$ & 0.576 & & & & Valid \\
\hline X2.10 & & 0.895 & & & Valid \\
\hline X2.2 & & 0.530 & & & Valid \\
\hline
\end{tabular}

\begin{tabular}{|c|c|c|c|c|}
\hline X2.3 & & 0.718 & & Valid \\
\hline X2.4 & & 0.684 & & Valid \\
\hline $\mathrm{X} 2.7$ & & 0.587 & & Valid \\
\hline X2.8 & & 0.895 & & Valid \\
\hline X2.9 & & 0.580 & & Valid \\
\hline XI.6 & 0.726 & & & Valid \\
\hline Y1.2 & & 0.787 & & Valid \\
\hline Y1.3 & & 0.875 & & Valid \\
\hline Y1.4 & & 0.514 & & Valid \\
\hline Y1.6 & & 0.538 & & Valid \\
\hline Y1.8 & & 0.710 & & Valid \\
\hline Y2.11 & & & 0.571 & Valid \\
\hline $\mathrm{Y} 2.12$ & & & 0.744 & Valid \\
\hline Y2.8 & & & 0.696 & Valid \\
\hline Y2.9 & & & 0.677 & Valid \\
\hline
\end{tabular}

Gambar tampilan hasil PLS untuk uji validitas instrumen penelitian. Dari tabel 9 dan gambar rata-rata memiliki loading item $>0,50$ dianggap valid. Hal ini disimpulkan bahwa kuesioner yang telah memenuhi convergent validity yang baik, sedangkan item yang memiliki loading $<0,50$ dianggap tidak valid sehingga belum memenuhi convergent validity yang baik. Sedangkan item yang memiliki nilai loading $<0,50$ dianggap tidak valid sehingga belum memenuhi convergen validity yang baik.

Gambar. 2 Tampilan Hasil PLS

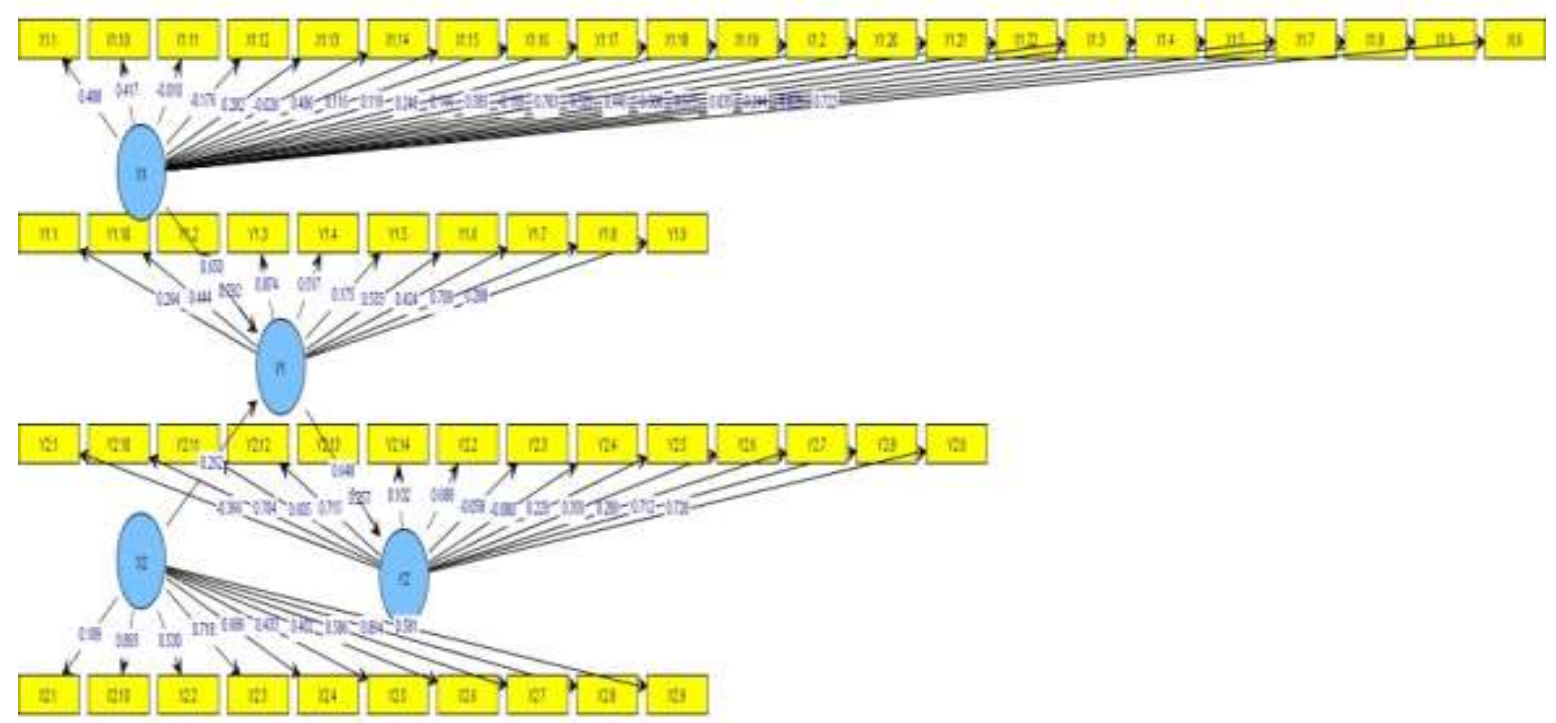





\section{B. Discriminant Validity}

Dari hasil cross loadings diperlihatkan bahwa untuk indikator Karyawan mudah berkomunikasi dengan rekan kerja di perusahaan, nilai kolerasi tertinggi ada pada variabel laten stres (angka yang dicetak tebal). Indikator Perusahaan tidak memberikan bonus kepada karyawan, nilai kolerasi tertinggi ada pada variabel laten kepuasan (angka yang dicetak tebal). Indikator menampilkan dirinya dengan baik seperti yang seharusnya, nilai kolerasi tertinggi ada pada variabel laten kinerja (angka yang dicetak tebal). Berdasarkan hasil tersebut dapat di interpretasikan bahwa model telah memenuhi discriminant validity.

\section{Composite Realibility}

Model pengukuran ketiga adalah Composite Realibility, yaitu kelompok indikator yang mengukur sebuah variabel memiliki reliabilitas komposit yang baik jika memiliki nilai lebih besar dari 0,70, walaupun bukan merupakan standar absolute (Solimun, 2011). Berdasarkan hasil pengukuran Composite Realibility instrumen dapat dikatakan reliable walaupun ada nilai yang kurang dari 0,70 karena nilai tersebut mendekati nilai 0,70 maka dianggap reliable.

Tabel 7. Composite Realibility untuk Uji Reliabilitas Instrumen Penelitian

\begin{tabular}{lcl} 
& $\begin{array}{c}\text { Composite } \\
\text { Reliability }\end{array}$ & Reliabilitas \\
\hline Stres $(\mathrm{X} 1)$ & 0,689 & Reliable \\
\hline Disiplin $(\mathrm{X} 2)$ & 0,852 & Reliable \\
\hline Kepuasan $(\mathrm{Y} 1)$ & 0,784 & Reliable \\
\hline Kinerja $(\mathrm{Y} 2)$ & 0,548 & Reliable \\
\hline
\end{tabular}

\section{Pengujian Hipotesis}

Dasar yang digunakan dalam penguijian hipotesis untuk menerima atau menolak hipotesis adalah output PLS result for inner weight yang ditunjukan pada tabel berikut:

Tabel 8. Result for Inner Weight untuk Menguji Hipotesis

\begin{tabular}{lccccc}
\hline & $\begin{array}{c}\text { Original } \\
\text { sample } \\
\text { estimate }\end{array}$ & $\begin{array}{c}\text { Mean of sub- } \\
\text { sample }\end{array}$ & $\begin{array}{c}\text { Standar } \\
\text { deviation }\end{array}$ & t-statistic & Hubungan \\
\hline Stres $\rightarrow$ kepuasan & 0,651 & 0,654 & 0,069 & 9,464 & Signifikan \\
\hline Disiplin $\rightarrow$ kepuasan & 0,257 & 0,265 & 0,081 & 3,190 & Signifikan \\
\hline $\begin{array}{l}\text { Kepuasan } \rightarrow \\
\text { Kinerja }\end{array}$ & 0,674 & 0,697 & 0,257 & 2,617 & Signifikan \\
\hline
\end{tabular}

Hasil estimasi PLS menunjukan bahwa:

1. Nilai t-statistic jalur pengaruh Stres terhadap Kepuasan adalah 9,464, dan terhadap Kepuasan serta Kinerja adalah 2,617 lebih besar dari t-tabel distribusi normal $(1,96)$, berarti signifikan, hipotesis 1 diterima.

2. Nilai t-statistic jalur pengaruh Disiplin terhadap Kepuasan adalah 3,190 dan terhadap Kepuasan serta Kinerja adalah 2,617 lebih besar dari t-tabel distribusi normal $(1,96)$, berarti signifikan, hipotesis 2 diterima.

3. Nilai t-statistic jalur pengaruh Kepuasan terhadap Kinerja adalah 2,617 lebih besar dari t-tabel distribusi normal $(1,96)$, berarti signifikan, hipotesis 3 diterima.

\section{E. Koefisien Determinasi Total}

Goodness of Fit Model diukur menggunakan $\mathrm{R}$-square variabel laten dependen dengan interpretasi yang sama dengan regresi. Qsquare predictive relevance untuk model struktural, mengukur seberapa baik nilai observasi yang dihasilkan oleh model dan juga estimasi parameternya. Nilai Q-square lebih besar dari (>) 0 menunjukan model memiliki predictive relevance, sebaliknya jika nilai Q-square lebih kecil atau sama dengan $(\leq) 0$ menunjukan model kurang memiliki predictive relevance (Solimun, 2011). Q-square dihitung dengan formulasi sebagai berikut:

$$
\mathrm{Q}^{2}=1-\left(1-\mathrm{R}_{1}^{2}\right)\left(1-\mathrm{R}_{2}^{2}\right) \ldots \ldots\left(1-\mathrm{R}_{\mathrm{p}}^{2}\right)
$$

Hasil output PLS menunjukan nilai Rsquare sebagai berikut:

Tabel 9. R-square

\begin{tabular}{cc}
\hline & R-Square \\
\hline Stres $(\mathrm{X} 1)$ & \\
\hline Disiplin (X2) & \\
\hline Kepuasan (Y1) & 0,650 \\
\hline Kinerja (Y2) & 0,454 \\
\hline
\end{tabular}

R-Square dimasukan kedalam rumus tersebut diatas, maka didapatkan nilai:

$$
\mathrm{Q}^{2}=1-(1-0,650)(1-0,454)=0,809
$$




\section{Kesimpulan}

Berdasarkan hasil penelitian yang telah dilakukan, diperoleh beberapa kesimpulan berikut ini:

1. Stres, disiplin, kepuasan dan kinerja di PT.

Bank Perkreditan Rakyat (BPR) Mitrathama

Arthabuana mempunyai pengaruh satu sama lain.

2. Stres dan Disiplin mempunyai pengaruh parsial terhadap kepuasan karyawan PT. Bank Perkreditan Rakyat (BPR) Mitrathama Arthabuana.

3. Stres dan Disiplin mempunyai pengaruh parsial terhadap kinerja karyawan PT. Bank Perkreditan Rakyat (BPR) Mitrathama Arthabuana.

4. Kepuasan berpengaruh terhadap Kinerja karyawan PT. Bank Perkreditan Rakyat (BPR) Mitrathama Arthabuana.

\section{Daftar Pustaka}

Dessler, Gary, Manajemen Personalia Edisi Ketiga (Terjemahan), 1984 Erlangga, Jakarta.

Handoko,T. Hani, Manajemen Personalia dan Sumber Daya Manusia, 2001, Liberty, Yogyakarta.
- Manajemen Personalia dan Sumber Daya Manusia Edisi 2, 2012.BPFE, Yogyakarta.

Kasmir, Dasar-Dasar Perbankan, 2002, Rajawali Pers, Jakarta.

L. Draft Ricard, Era Baru Manajemen Edisi 9 Buku 2 (Terjemah),2012, Salemba Empat, Jakarta.

Malayu SP, Hasibuan, Manajemen Sumber Daya Manusia, 2007, PT Gunung Agung, Jakarta.

Manulang. M, Pengantar Bisnis, 2002, Gadjah Mada University Press, Yogyakarta.

Sekaran Uma, 2006. Research Methods For Business: Metodologi Penelitian Untuk. Bisnis, Jilid 1 dan 2,

Salemba Empat, Jakarta.

Siagian Sondang P, Sumber Daya Manusia, 1998, Bumi Aksara, Jakarta.

Solimun, 2011. Aplikasi Statistika PLS: Struktur Equation Modeling (Metode PLS Partial Least Square). FMIPA dan program Pascasarjana Universitas Brawijaya, Malang.

Sunarto, Manajemen 2, 2007, Amus, Yogyakarta.

Taswan, Manajemen Perbankan: Konsep, Teknik dan Aplikasi Edisi II, 2010, UPP STIM YKPN: Yogyakarta.

, Akuntansi Perbankan: Transaksi Dalam Valuta Rupiah, Edisi Revisi, 2003, UPP STIM YKPN, Yogyakarta. 